\begin{tabular}{l|c|c|}
\hline DE & $\substack{\text { DE GRUYTER } \\
\text { OPEN }}$ & ECONOMIC THEMES (2014) $52(4): 461-479$ \\
& DOI 10.1515/ethemes-2014-0028 \\
\hline
\end{tabular}

\title{
THE NORMATIVE BASIS OF FINANCIAL REPORTING OF THE SMALL AND MEDIUM-SIZED ENTITIES OF THE REPUBLIC OF SERBIA
}

\author{
Tadija Đukić \\ University of Niš, Faculty of Economics, Serbia \\ \tadija@eknfak.ni.ac.rs
}

Miloš Pavlović

University of Priština, Faculty of Economics Kosovska Mitrovica, Serbia

$\bowtie$ milos.pavlovic@pr.ac.rs

UDC

657.375:

334.012.63/.64

Review paper

Received:

28.11.2014

Accepted:

29.12.2014

\begin{abstract}
Small and medium-sized entities represent a special group of entities in the economy of a country in terms of organization and structure of financial reporting primarily for external users. The publication of the International Financial Reporting Standards for Small and Medium-sized Entities reveals that the International Financial Reporting Standards are not aligned with the capabilities of small and medium-sized entities, and that they are the basis of the second level of financial reporting. The main task and the goal of IFRS for the SMEs is to simplify the existing accounting regulations for this segment of the company. They have identified the specific needs of the financial reporting of small and medium-sized entities and specific information requirements of this part of the economy. Ease of application through a simpler option valuation and disclosure decreased, reducing the cost of preparing the report, as well as continuity, represent some of the advantages of the new standard.

Keywords: International Financial Reporting Standards, International Financial Reporting Standard for Small and Medium-sized Entities, the financial statements, SMEs, Republic of Serbia
\end{abstract}

\section{Introduction}

Accounting standards that are the basis for the preparation of transparent and comparable accounting information presented in the form of basic financial statements. Application of International Financial Reporting Standards as highly complex, specialized and demanding substances requires a certain knowledge, 
experience, time or a legal obligation for certain business entities in the Republic of Serbia. Consistent application of IFRS to business entities in addition to International Financial Reporting Standards (IFRS) represent a unique set of high quality global fulfilling legal obligations to meet the information needs of different stakeholders with an interest has certain benefits or problems. Problems with IFRS are mostly of a practical nature and are reflected in the difficulties faced by the accounting practices in their everyday usage. The benefits of standardized financial reporting are multiple. First, it allows the formation of a single capital market and maintain its stability, which leads to a reduction in the cost of capital. Second, the comparability of financial statements enables more efficient allocation of capital. Furthermore, they represent a vital link between managers and investors. Also, the accounting staff develops internationally recognized skills preparation, compilation and disclosure of financial statements.

In most cases, IFRS are applied only large entities that have public accountability. And the benefits of globalization should have, and other entities, regardless of their size and access to capital, primarily small and medium-sized entities. For these reasons, the International Accounting Standards Board (IASB) in 2000 identified the need for a special version of the international accounting standards for small entities. In June 2004, the IASB published a preliminary review of standards for small and medium-sized entities. Finally, after the above draft and reconciliation, International Financial Reporting Standard for Small and Medium-sized Entities (IFRS for SME) was released on 9 June 2009.

IFRS for small and medium-sized entities was created in accordance with the user's needs, taking into account the costs and benefits in providing the information. The benefits of this standard are ease of application through a simpler option valuation, reduced disclosure, reducing the cost of preparing the statements, specific accounting principles that are suitable for small and medium-sized entities that are not quoted on the stock exchange and have IFRS as its basis.

In the first part of this paper will discuss the definition and importance of small and medium-sized entities, both at the level of the European Union and the Republic of Serbia. The second part of the paper will identify the reasons why IFRS does not represent the exemplary normative basis for the small and medium-sized entities. The third part of the paper will highlight the basic features of international financial reporting standards for small and mediumsized entities.

\section{The Importance of the Definition of Small and Medium-sized Entities}

Small and medium-sized entities have a significant role in the economy. What is evident is the representation of small and medium-sized entities 
according to the number of registered businesses, so it could be said that the same contribute to a greater extent to the economic development of the country. Small and medium sized entities are the main pillar and a key resource for economic growth, dynamism and flexibility, both in developed, developing and industrial countries and in emerging economies.

Developed countries, thanks especially to small and medium-sized entities exercise the predominant part of their successful economic and social development. This can be explained by the following facts: small firms can more easily adapt to the demands of the market, achieve higher profitability compared to large firms in relative terms, effectively overcome the resulting disturbances in the environment, they can also work with a relatively small volume of invested capital, relatively easy to enter and exit certain economic areas, often in the hands of members of wider and closer family and are strongly interested in the survival, growth and development of businesses and they can reduce the risk of unsuccessful operations and work without a loss (Petković, Berberović, 2013, p. 2).

In the literature we can find many definitions of small and medium-sized entities. Prior to the adoption of a common definition at the EU level, there are several different definitions of SMEs. Thus, in the UK small entities were defined as subjects who have up to 200 employees, in France, the number of employees in small entities ranged from 6 to 50 workers, and medium from 51 to 500 employees. In Germany, for the definition of small and medium-sized entities, in addition to the number of employees, the total annual income was taken into account. (Radulovic, 2006, pp. 25-26).

According to the OECD definition, small and medium-sized entities with fewer than 500 employees, although each country leaves room for this number to increase or decrease (in some countries, 100 or even 300 employees represent the upper limit). Micro-entities have 1-4 employees, very small 5-19, small and medium-sized entities 20-99 and 99-500 employees, respectively. (Dostić 2003, pp. 23-34)

According to the World Bank, the division of the entity carried out in the manner is provided in Table 1.

Table 1. The classification of entities according to the World Bank

\begin{tabular}{|l|c|l|l|l||}
\hline Entity category & $\begin{array}{c}\text { Number of } \\
\text { employees }\end{array}$ & Total income & or & $\begin{array}{c}\text { The total ampunt of } \\
\text { the balance }\end{array}$ \\
\hline Medium entity & $<300$ & $\leq 15$ mil. eur & $\leq 3$ mil. eur \\
\hline Small entity & $<50$ & $\leq 3$ mil. eur & $\leq 3$ mil. eur \\
\hline Micro entity & $<10$ & $\leq 0.1$ mil. eur & $\leq 0,1$ mil. eur \\
\hline
\end{tabular}


Within the European Union, the first official definition of small and medium-sized entities was made on April 3, 1996. At the European Council in Feira 19-20 June 2000, the European Charter for Small Entities was approved. The charter states that small entities are the backbone of the European economy, a key source of employment and a foundation for the development of business ideas. "In Lisbon, we established the goal of making the European Union the most competitive and dynamic economy in the world, based on knowledge, skills for sustainable economic growth, more and better employment and greater social cohesion. Small entities must be seen as the main drivers of innovation, employment, and also social and local integration in Europe "(Council of Europe, 2000, p. 1).

In this way, the importance of small entities and entrepreneurs for development, competitiveness and employment in the European Union was fully recognized. Consequently, the European Commission on 6 May 2003 adopted a recommendation for the adoption of a new definition of SMEs. Small and medium- sized entities were defined in EU legislation in the EU Recommendation 2003/361, which was published in the Official Journal of the European Union L 124, p. 36 of 2003. Recommendation entered into force on 1 January 2005 and is the only valid basis for determining the conditions for the classification of entities as SMEs. The definition of small and medium-sized entities is as follows: "A group of micro, small and medium-sized entities include entities that employ up to 250 workers, whose annual turnover does not exceed EUR 50 million, and / or the sum of the balance does not exceed EUR 43 million" (Recommendation of the European Commission in 2003/361, Section 2 of the Annex to Recommendation).

According to the above recommendation of the European Commission, the entities can be divided into micro, small and medium. For the above classification of entities, it is necessary to take into account three criteria: the number of employees, total revenue and total amount balance.This could be summarized as follows:

Table 2. Classification of entities as defined by the EU

\begin{tabular}{||l|c|l|l|l||}
\hline Entity category & $\begin{array}{c}\text { Number of } \\
\text { employees }\end{array}$ & Turnover & or & $\begin{array}{c}\text { The total ampunt of } \\
\text { the balance }\end{array}$ \\
\hline Medium entity & $<250$ & $\leq 50$ mil. eura & $\leq 43$ mil. eura \\
\hline Small entity & $<50$ & $\leq 10$ mil. eura & $\leq 10$ mil. eura \\
\hline Micro entity & $<10$ & $\leq 2$ mil. eura & $\leq 2$ mil. eura \\
\hline
\end{tabular}

Source: European Commission, The New SME Definition, User guide and model declaration, 2012, p. 14. 
A common definition of SMEs at the European Union level, is used as the basis for legislative decisions in the EU state aid and structural funds. This means that micro, small and medium-sized entities must be defined in a way that ensures economic fairness, i.e. firms that provide legal certainty, while the legal systems of the Member States allows for easy application.

Micro, small and medium-sized entities represent $99 \%$ of all entities in the EU, as illustrated in Table 3, and there are about 21 millions $f$ them. They employ about 33 million people (more than $67 \%$ of the total number of employees) and make a key source of entrepreneurial spirit and innovation, which are crucial for the competitiveness of the entities in the EU. The goal of EU policy in the field of small and medium enterprises is to ensure that policies and measures are tailored to small entities, as well as to contribute to increase in the attractiveness of Europe for the establishment and operations of the entity. (Fact Sheets on the European Union - 2014).

Table 3 Structure of entities in the $\mathrm{EU}$ according to the size and number of employees

\begin{tabular}{|l|r|r|r|}
\hline \multicolumn{1}{|c|}{ Size of entities } & \multicolumn{1}{c|}{$\begin{array}{c}\text { Number of } \\
\text { entities in EU }\end{array}$} & \multicolumn{1}{|c|}{$\begin{array}{c}\text { Percentage } \\
\text { share }\end{array}$} & $\begin{array}{c}\text { Percentage share in } \\
\text { total employment }\end{array}$ \\
\hline Micro entities & 19.279 .555 & 91,8 & 29,6 \\
\hline Small entities & 1.450 .000 & 6,9 & 20,8 \\
\hline Medium entities & 228.209 & 1,1 & 16,8 \\
\hline Large entities & 45.184 & 0,2 & 32,8 \\
\hline Total & 21.002 .956 & $100 \%$ & $100 \%$ \\
\hline
\end{tabular}

Source: (Gulin, 2013, str. 34)

The Republic of Serbia divided entities into micro, small, medium and large. The above classification of entities was carried out according to Article 6 of the Law on Accounting (2013) on the basis of three criteria: the average value of operating assets, operating revenue and average number of employees. That the entity would be classified into one of these categories should fulfill two of the three criteria.

Table 4 Distribution of the entities in the Republic of Serbia

\begin{tabular}{|l|r|r|r|}
\hline \multicolumn{1}{|c|}{ Size of entities } & \multicolumn{1}{c|}{$\begin{array}{c}\text { Entity average } \\
\text { assets }\end{array}$} & $\begin{array}{c}\text { Operating income } \\
\text { in EUR }\end{array}$ & $\begin{array}{c}\text { Average number } \\
\text { of employees }\end{array}$ \\
\hline Large entities & Over 17.500 .000 & Over 35.000.000 & Preko 250 \\
\hline Medium entities & 17.500 .000 & 35.000 .000 & Do 250 \\
\hline Small entities & 4.400 .000 & 8.800 .000 & Do 50 \\
\hline Micro entities & 350.000 & 700.000 & Do 10 \\
\hline
\end{tabular}


The importance of small and medium-sized entities in Serbia are illustrated by the basic indicators (Report on SMEs and Entrepreneurship for 2012, 2013, p. 8). In 2012, from a total of 317668 companies, entrepreneurial sector accounts for $99.8 \%$ (317 162 companies). SMEs generated $65.1 \%$ of employees (782,026), $65.4 \%$ of turnover (5.690 billion dinars), $55.8 \%$ of GVA (977.1 billion) and employ $45.5 \%$ of the non-financial sector investments. SMEs employ $45.3 \%$ of total employment, $39.1 \%$ of total investments, realizes $49.8 \%$ of exports, $58.2 \%$ of imports, generating $70.8 \%$ of the foreign trade deficit in the Serbian economy and accounts for about 33\% of the GDP of the Republic of Serbia. Broken down by size, the structure of the SME sector includes largely micro enterprises (305 321), while small and medium enterprises $(11,841)$ dominate at all observed indicators (53.8\% of employment, $60.7 \%$ of turnover, $61.6 \%$ of GVA, $77,0 \%$ of exports, imports $74.5 \%$ of SMEs).

\section{The Need for IFRS for SMEs}

International Financial Reporting Standards are, primarily, but not exclusively, aimed at reporting entities which act in the financial markets or, more accurately, reporting entities that have public accountability. ${ }^{1}$ These standards are applied as required or permitted in more than 130 countries worldwide. In a small number of countries - about 30 international financial reporting standards used for reporting all entities, while in others, some 100 countries, international financial reporting standards used for reporting entities that have public accountability.

Publicly accountable entities are characterized by a large number of limited liability of the owner, the separation of owners and management. For existing and potential investors to make decisions, the information about the financial position, operating performance and cash flows of the entity are needed. Meeting the information needs of these users is the main goal of a global system of financial reporting, and international financial reporting standards are widely accepted instrument for achieving them. The information presented in the financial statements prepared in accordance with International Financial Reporting Standards for investors and creditors is a valid basis for identifying risks with which business entities are affiliated, assessment of exposure to these risks and for forecasting future performance of the entity. This is because this information is characterized by relevance, credible presentation, timeliness, comparability, intelligibility and verifiability.

\footnotetext{
${ }^{1}$ An entity has public accountability if: 1) submits or is in the process of filing its financial statements to the Commission for Securities for the purposes of issuing securities that are traded in a public market; and 2) as one of the core business activities, as trustee holds property of a large group of external parties. A typical example are banks, credit organizations, insurance companies, brokers and dealers, mutual funds and investment banks.
} 
Small and medium- sized entities usually have modest capital, a small volume of business activity, a small number of employees, the separation of the ownership and control functions is not conducted but are mostly owners and managers. The additional equity in these entities is usually invested into without public calls by existing or new owners. The necessary resources mean these entities are coming by borrowing from banks and other financial institutions. Due to these characteristics of small and medium-sized entities a shortlisted user is interested in more modest and slightly different information about their business.

Due to the fact that the owners of the entity are usually managers, who are sometimes part of the management structure and that few of them have access to all necessary information, the most frequent users of information on small and medium-sized entities are creditors, government, customers, suppliers and employees . The most common creditors of these entities are banks, which have the necessary information required for the assessment of their creditworthiness, i.e. the evaluation of the ability to service the loan obligations throughout the period of repayment. The state, through the financial statements follows the operations of these entities in order to evaluate the success of their economic policies. This is because the state provides special support for the development of these entities. Customers are interested in information which can estimate the survival and development of the entities, particularly where they are dependent on such entities. Suppliers are interested in information about whether the amount owed to them by others will be paid on time. The employees have the necessary information about the stability of the entity and its profitability, in terms of estimates of certainty and wages, hiring new workers, changing jobs, etc.

Consequently, the international financial reporting standards have become aligned with the needs of small and medium-sized entities, primarily due to the complexity of the requirements related to the assessment, the number of rights of choice and a lot of information that should be disclosed. Application of International Financial Reporting Standards as the basis for financial reporting of small and medium-sized entities becomes uneconomical, because it causes the costs exceed the benefits because it generates information that is not relevant to users. The users of the financial statements of small and mediumsized entities, have expressed the need for examining the short-term inflows and outflows of cash, liquidity, financial strength of the entities, the degree of coverage of interest and information on the movement of financial results in the past as financial statements prepared in accordance with IAS / IFRS provide information to investors and creditors should help in forecasting the long-term cash flows of the entity, gains or losses and its values.

In order to accept the demands for simplifying the reporting of small and medium-sized entities, the requirements in terms of standardization and harmonization of their reporting, the International Committee on Standards for 
Financial Reporting started developing specific standards for financial reporting of small and medium-sized entities. In mid-2009, the IASB issued IFRS for small and medium-sized entities, as well as a customized basis for their financial reporting. About how the decision was justified IASB is the fact that around 90 countries worldwide directly applied IFRS for the SME or brought national legislation in line with the content of IFRS for SME (Stojanovic, 2014, p. 6).

The adoption and implementation of IFRS for SME as a basis for financial reporting by these entities can bring multiple benefits (Škarić Jovanovic, 2011, 22):

- Globally recognized basis of financial reporting raises the confidence of users in the quality of financial statements drawn up,

- Implementation of standards ensures obtaining transparent and globally comparable financial reports,

- Raising the quality of financial reporting facilitates access to sources of capital to small and medium-sized entities,

- From the point of view of the composer, the application of these standards ensures the existence of a balanced relationship between the costs and benefits of the presented financial statements.

By accepting IFRS for the SME as a basis for financial reporting of small and medium-sized entities cease to be a need for the adoption and permanent maintenance of national accounting standards.

\section{Framework for Financial Reporting of SMEs}

4.1. General characteristics of financial reporting for small and mediumsized entities

In Serbia there has been a longstanding practice in the application of International Financial Reporting Standards. The obligation of their application related to all business entities, regardless of their size. The adoption of the Accounting Act of 2013 stipulates that a large entities, entities that prepare consolidated financial statements, public companies and medium entities that can decide for themselves apply International Financial Reporting Standards. International Financial Reporting Standard for Small and Medium-sized Entities apply intermediate entities who decide to implement them, then small entities, the largest number of legal entities and micro-entities.

Considering that the aim of building a consistent basis IASB financial reporting globally to both pillars of financial reporting, IFRS and IFRS for the SME based on the same core concepts and principles. The existence of this link is necessary because it creates a possibility to compare not only the financial statements within each level of reporting, but also between them; facilitates the training of accountants, auditing and reporting transition from IFRS to IFRS for 
SMEs and vice versa. Using the same concepts and principles of both levels of financial reporting is possible because IFRS and IFRS for the SME are the basis for the preparation of general purpose financial statements.

Getting less complex and yet understandable relevant information to their users, which are easier for the application of IFRS for small and medium-sized entities in relation to IFRS, is realized in several ways:

- Turning off the standards that deal with issues that are of importance to small and medium-sized entities,

- Simplification of rules for recognition, classification and valuation of assets, liabilities, income and expenses,

- Reducing the required disclosures relating to transactions and economic circumstances that were adopted standards and

- Using simpler language for writing standards (Škarić, 2011, p. 27).

Significant differences between International Financial Reporting Standards for Small and Medium-sized Entities (IFRS for SMEs) and International Financial Reporting Standards is in the scope of regulation. That is, IFRS has about 2900 pages and IFRS for SMEsE only 230 pages. IFRS for SMEs represent a single standard that consists of thirty-five sections. On the other hand, for entities with public accountability aside from the conceptual framework for financial reporting, 41 standards and 33 presentations (interpretation) and thirteen IFRS have been published.

Reducing the IFRS for SMEs in relation to IFRS was made on the basis of omitting certain topics and simplified recognition and measurement of items in the financial statements. So IFRS for SMEs represent a reduced content, which are omitted certain topics from IFRS because they are not of importance to private entities whose securities are not traded on a public market, where IFRS offer a greater number of options for IFRS MSE has taken only one and a simpler option or solution. Some of the topics that are left out in IFRS for the MSE: segmental reporting, periodic reporting, earnings per share, insurance, assets held for sale.

Reducing the content was done on the basis of a simplified recognition and measurement, which is primarily related to: financial instruments, impairment, goodwill amortization, expenses for research and development, to reduce the application of the fair value option when valuing assets, treatment of financing costs, then when the first application this standard requires significantly less data from the previous period.

In IFRS, there are about 3,000 requests for disclosures while in IFRS for SME the number of requests decreased ten times and is about 300 requests for disclosure in the notes to the financial statements. 
The objective of financial statements of small and medium-sized entity is to provide information about the financial position, performance and cash flows of an entity that is useful for economic decision-making diverse users, who are not in a position to demand reports that they need. At the same time, the financial statements should show the results of management control in terms of management responsibility for the resources entrusted to them.

A complete set of financial statements under IFRS for the SMEs represents: a report on the financial position, a statement of comprehensive income or separate income statement and a separate statement of comprehensive result, statement of changes in equity for the reporting period, cash flow statement and notes to make a brief overview significant accounting policies and other explanatory. That is, it is evident that there is no difference in the set of financial statements in large and small and medium-sized entities.

\subsection{The Qualitative Characteristics of Financial Statements}

The qualitative characteristics of financial statements under IFRS for the SMEs: understandability, relevance, materiality, reliability, substance over form, prudence, completeness, comparability, timeliness, balance between benefit and cost. All qualitative characteristics are given equal footing and with the same character.

Intelligibility is an essential quality of information in the financial statements that enables users to understand its meaning. The financial statements are required to be prepared so that users can immediately understand the information they contain. Understanding of the information is provided by selecting and marking them as stated accounting category (Krstic et al., 2013, p. 397).

Relevance - the ability of information that can help you make informed decisions. In other words, under the relevant financial information is considered information that is appropriate to meeting the needs of users in content, scope, time and method of preparation (Krstić, 2002, p. 20).

Materiality is such a characteristic of accounting information where its omission or mis-expression could influence the economic decisions of users taken on the basis of such financial statements. Materiality depends on the size of the item or error assessed in the particular circumstances of its omission or misstatement formulation.

Reliable information when it was in its no material errors or biases when faithfully represents the business transactions or which could reasonably be expected that it represents. Financial statements are not free of prejudice if the selection or presentation of information in them is intended to influence the decision or judgment in order to achieve a pre-determined result or outcome. 
Substance over form, means that business transactions and events should be accounted for and presented in accordance with their substance and not merely on the basis of their legal form. This increases the reliability of financial statements.

Prudence is the inclusion of a certain degree of caution in the judgment necessary for the assessment required by the conditions of uncertainty, such that assets or income are not overstated and liabilities or expenses are not understated. However, the use of prudence does not allow the deliberate understatement of assets or income, or the deliberate overestimation of liabilities or expenses. That is, prudence does not allow prejudice.

The complete information from those who have not made omission that could affect the information to be false or misleading and thus unreliable and deficient.

The comparability of such characteristics of accounting information that enables you to compare the financial statements of an entity in order to identify trends in terms of its financial position and operating performance. At the same time, users must be able to compare the financial statements of different Entity to assess their relative financial position, performance and cash flows. Therefore, measurement and presentation of the financial effects of similar transactions and other events and conditions must be done consistently throughout the entity and overtime for that entity, and consistently for different entities. In addition, users must be informed of the accounting policies used in preparing the financial statements, as well as all changes in those policies and the effects of such changes.

Timely information that she is able to timely influence the economic decisions of users. Timeliness involves providing information for the period necessary for the decision. If there is undue delay in reporting, information can lose its relevance. The management entity must harmonize the benefits of timely reporting and the provision of reliable information.

The balance between benefit and cost is achieved in a situation where the benefits to be gained from the information outweigh the costs of obtaining such information. The assessment of benefits and costs is essentially a process of discernment. Buyers do not have to be borne by those users who enjoy the benefits, because the information that it uses a wide range of users.

Under IFRS, there are basic and qualitatively improving the characteristics of information in the financial statements. Basic characteristics qualitatively accounting information relevance and authentic presentation. Relevance byproducts are: predictive value and verify the value, a credible presentation: completeness, neutrality and the absence of material misstatement. Improving characteristics (comparability, verifiability, timeliness and understandability) 
have the task to improve the quality of financial information that is relevant and faithfully presented in the financial statements.

\subsection{Recognition, Classification and Valuation of the Financial Statement}

Evaluation of balance positions according to IFRS guidelines for SMEs is performed on the basis of historical cost. However, investment properties and biological assets are measured at fair value. All other items that are not carried at fair value are subject to the determination of impairment.

When selecting accounting policies IFRS for SMEs suggests that when this standard does not deal with the concrete transaction or business event, management should define the accounting policies that will result in relevant and reliable information to the effect that the financial statements:

- faithfully represent the financial position, financial performance and cash flows,

- reflect the economic substance of transactions,

- be neutral, ie devoid of subjectivity,

- careful in the sense that it does not contain any unnecessary risks,

- be complete with all material respects.

When assessing the accounting policies, management considers the requirements of IFRS for the SMEs or the complete set of IFRS requirements or guidelines dealing with similar issues. When IFRS guidelines dealing with the accounting policies, suggest that when there is no standard treats specific business transaction or business event, management should select an accounting policy that is consistent with the financial reporting framework.

Nonfinancial assets under IFRS for the SMEs includes inventories, investment property, property, plant and equipment, intangible assets and impairment of assets.

Definition of stocks, their recognition, measurement, determining cost, conversion costs, allocation of overhead costs of production, the cost of inventories service providers, impairment of inventories and expense recognition on the basis of the stock, are questions that are similarly defined in both IFRS and in IFRS for SMEs. Section of stocks is given in simplified and abbreviated form exemplary small and medium-sized entities. The difference between IFRS and simplified standards is that with IFRS for the MSE is no possibility that the borrowing costs are capitalized and included in the value of stocks, but they are considered unconditional expenditure.

The definition of investment property under IFRS for the MSE is similar to the definition given in IAS 40 - Investment property. Initial measurement is similar in both frames, except that IFRS allows the borrowing costs capitalized 
and included in the cost of investment property, unlike IFRS for the SMEs, which does not contain such a possibility. Regarding the evaluation after the initial recognition standard for small and medium-sized entities indicates that all investment property that can reliably determine fair value without excessive costs, upon initial recognition at fair value, while investment property, for which no large costs can not determine the fair value upon initial recognition are measured at cost.

Property, plant and equipment at the IFRS for SMEs covered by the guidelines section 17. In the initial recognition of property, plant and equipment with IFRS, it is allowed to borrowing costs are included in the cost of property, plant and equipment, while such a possibility is not included in the standard small and medium-sized entities, as borrowing costs are recognized as expenses in the period in which they are incurred.

In terms of valuation after the initial recognition of IFRS for SMEs refer exclusively to the cost model, without using the revaluation model. The treatment of the residual value that affects the determination of the basis for the calculation of depreciation, also differs in these two regulatory frameworks in that IFRS requires an annual review of the residual value, lifetime and method of calculating the depreciation of property, plant and equipment. IFRS for SMEs require this unfolding only if there is an indication that there has been a significant change since the last annual reporting.

Intangible assets other than goodwill with IFRS for the SMEs defined in section 18 and in IFRS guidance of Questions relating to the definition of intangible assets, the basic principles of recognition, the initial recognition and treatment of internally generated intangible assets, are similarly determined in both regulatory frameworks. Expenditure on research and development is the standard for small and medium-sized entities to fully consider expenditure, while under the guidance of IAS 38 expenditures for research expenditure and expenditure on development, if certain conditions are met, are recognized as intangible assets. Valuation after initial recognition under IFRS for the SMEs is conducted exclusively by the cost model without the possibility of using the revaluation model that allowed large standards.

The useful terms of intangible assets, on the basis of which by the rate of depreciation calculation is determined, according to the SMEs on the basis of contractual or legal rights, and believes that it must be comprehensive. If small and medium-sized entity is unable to estimate the useful life of certain intangible assets, the rate for the calculation of amortization should be determined based on the assumption that the useful life of the asset is ten years. On the other hand, the provisions of IAS 38 provides the possibility of entities that intangible assets have an indefinite useful life and that on that basis in such property is not subject to depreciation. Revisiting the amortization period, the 
method for calculating depreciation and the residual value, according to IAS 38 is carried out every year before the financial statements, while in the standards for small and medium-sized entities review is not done every year, but when there is an indication that there has been a change in residual values, methods for the calculation of depreciation and useful life.

Impairment of assets is the IFRS for SMEs is covered by Section 27. And according to IFRS and according to standard for small and medium-sized entities impairment loss occurs when the carrying value of an asset exceeds its recoverable amount. The differences in terms of impairment are as follows:

- Recognition of impairment loss under IFRS for the SMEs is performed on spending, according to paragraph 60 of IAS 36 - Impairment of Assets, the recognition of impairment is performed on expenditures, except when it comes to the means which are subsequently evaluated by the revaluation and that records was performed in revaluation reserves, it should execute a reduction in the revaluation reserve for the amount of the impairment.

- Under Section 27.7 annual review of indicators of impairment is performed for all the resources that are subject to devaluation, and if there are indications of impairment, the impairment test is carried out in order to determine the amount of impairment. The same obligation exists under IAS 36 , except that it additionally requires that the impairment test must be enforced at the end of the accounting period, regardless of whether the observed indications of impairment for the following assets: Intangible assets with an indefinite useful life and goodwill acquired in a business combination.

And according to large and small standard devaluation of goodwill is done indirectly through devaluation cash-generating unit to which goodwill belongs. In connection with allocating goodwill to cash-generating units, the standard for small and medium-sized entities are focused on the circumstances in which the goodwill cannot be allocated to cash-generating units and contains instructions for such circumstances, while IAS 36 does not contain such references.

In addition to these differences, IAS 36 deals with the specific issues related to the impairment that are not subject to the content standards for SMEs, such as user estimate of recoverable amount and the impairment of mutual funds.

Capital. IFRS for SMEs contains a special section that relates to liabilities and equity, while in IFRS equity instruments granted for various standards. According to the standard for small and medium-sized entities, capital is defined as the remaining share in the assets of the entity after deducting all of its liabilities. Capital investment includes the owner of the entity, plus zoom through profitable operations minus impairment of investments due to unprofitable business owner. When the dictionary with IFRS standards data is 
somewhat narrower definition of capital: equity is the residual assets of the rest of the entity after deducting all of its liabilities.

Financial instruments, the standard for small and medium-sized entities are treated in sections 11 and 12 of the Code of IFRS on financial instruments concerning the following standards: IAS 32 - Financial Instruments: Presentation, IAS 39 - Financial Instruments: Recognition and Measurement and IFRS 7 - Financial Instruments: Disclosures.

Section 11 relates to the recognition, derecognition, measurement and disclosure of the underlying financial instruments (financial assets and financial liabilities). Entity in relation to financial instruments may opt to apply either Sections 11 and 12 of the IFRS for MSE or optional IAS 39. If an entity elects to apply IAS 39 for disclosure should apply to the requirements of Section 11 and 12 rather than IFRS 7

Initial recognition of financial instruments shall be made at the time when the entity becomes a party of agreement under which it occurs for a financial asset or financial liability. All basic financial instruments are measured at cost or amortized cost, except for investments in shares traded on the stock market, and whose fair value can otherwise be measured reliably. The basic financial instruments are cash, time deposits and demand deposits, commercial paper, and against loans, receivables and liabilities in respect of bills and loans, bonds and similar debt instruments. In determining the depreciated value applied to the effective interest method.

Financial instruments that are measured at cost or amortized cost, no later than the end of the accounting period are tested for impairment. If, in a subsequent accounting period to the eve of the impairment is reduced, it is possible to reverse the impairment. The shares are valued at fair value, which is determined on the basis of their listing on the stock exchange, and if it does not apply to any of the alternative methods of assessment of fair value.

Section 12 of the IFRS for MSE is governed by the accounting treatment of complex financial instruments such as options, forwards, swaps and other derivatives. In determining the initial complex financial instruments are measured at fair value, which is normally the transaction price. In a subsequent evaluation also applies fair value, and the effects of changes in fair value are recognized in the income statement.

Section 11 covers the most important disclosures provided in IFRS 7, relating to the risks. Disclosures relating to risk and are not explicitly included in section 11 of IFRS for MSE are required disclosures for financial institutions and disclosures required for companies whose securities are traded in public capital markets. 
The classification of financial instruments under Sections 11 and 12 was carried out on basic and complex financial instruments. According to paragraph 9 of IAS 39 Financial instruments are classified into four categories: financial assets or financial liabilities at fair value in the balance sheet, investments held to maturity, loans (loans) and receivables and financial assets available for sale. Given that these two classifications differ significantly and as with IFRS for the SMEs is no financial asset or financial liability at fair value in the income statement or financial assets available for sale, there is no requirement that the management at the time of acquisition of the financial instrument in accordance with the intention of disposing of the financial instrument perform their classification, as is the case with IFRS.

According to IFRS for the SMEs' financial instruments are derecognized when: cease to be valid contractual rights to the cash flows of the financial asset, the entity transfers substantially to the other side all the risks and rewards of ownership of the financial asset, the entity no matter what has kept the significant risks and benefits from the asset transfer to another party the right to sell the asset to a third party. According to IAS 39, paragraph 17, an entity should cease to recognize a financial asset when: expire contractual rights to the cash flows of the financial asset or a financial asset when transferred to any other legal or natural person. Guidelines relating to derecognition in both the above frameworks are quite similar, however IFRS include additional guidelines for contractual arrangements relating to financial instruments and relevant aspects of the transfer of funds.

Certain issues of financial instruments that are subject content of IFRS, are not considered content standards for small and medium-sized entities such as derivatives and derivative financial instruments, reclassification of financial instruments and hedging instruments qualify.

Expenses are under IFRS for the MSE covered by section 2, which refers to the definition of expenditure, Section 26 relating to payments on shares and employee benefits, and similarly covered at full IFRS guidelines.

The differences between the accounting treatment of expenditures with IFRS and IFRS for MSE exist in the treatment of borrowing costs because standard guidelines for small and medium-sized entities indicate that borrowing costs necessarily be treated as an expense, while IAS 23 - Borrowing costs indicate that borrowing costs included in the asset's carrying amount respectively, whose obtaining they were formed, if certain conditions are met. Other borrowing costs are recognized as expenses in the period in which they are incurred.

Revenues that are covered under IFRS for the MSE are almost identical as with IFRS. Accordingly, in a similar way as for the IFRS definition of regulated revenues, their recognition, measurement, classification, coverage of revenue 
arising from construction contracts and the inclusion of income in case of delayed payment.

\section{Conclusion}

Small and medium-sized entities play a significant role in all economies. They account for a significant contribution to increasing income and creating new jobs, encouraging innovation and development of new technologies and have direct impact on the level of aggregate demand and investment. Along with the rise of the problem of large companies in the field of organization and management, the importance of small and medium-sized entities continuously grew.

Taking into account the information needs of users of financial statements of small and medium-sized entities, their basic characteristics, developed by an international financial reporting standard for these entities. The main feature of this standard is the simplicity which is achieved by reducing existing international financial reporting standards applied by the company to a public company. Getting less complex and comprehensive standards for small and medium-sized entities realized by switching off the standards that are relevant to their business, by simplifying the recognition and valuation of balance sheet and income statement, reducing the required disclosure and use of plain language for writing standards.

For countries that have so far applied IFRS for all entities, which includes the Republic of Serbia, the adoption of IFRS for the MSE should facilitate financial reporting by small and medium-sized entities, facilitate international comparability and to ensure continuity in reporting.

\section{References}

A Guide to the IFRS for SMEs, (2010) IASC Foundation Publications Department, London.

Bonić, Lj. and Đorđević, M. (2013) Kontrola kvaliteta i javni nadzor eksterne revizije, Ekonomske teme, 51(2): 335-353.

Dostić, M. (2003) Menadžment malih i srednjih preduzeća, Ekonomski fakultet Univerziteta u Sarajevu, Sarajevo

Đukić, T. and Pavlović, M. (2014) Kvalitet finansijskog izveštavanja u Republici Srbiji, Ekonomske teme, 52(1): 101-116.

European Commission, (2012) The New SME Definition, User guide and model declaration.

Evropska komisija, (2003) Preporuka 2003/361, dostupno na http://eur-lex.europa.eu/ legal-content/EN/ALL/ELX_SESSIONID=C5KJJMWC7whQ5Y5G2f72qYbmspt7 
vyhJPNnWbrL3kD2vm1jVc22k!-921735665?uri=CELEX:32003H0361

(pristupljeno 25.11.2014.)

Fact Sheets on the European Union - (2014), dostupno na www.europarl.europa.eu/ aboutparliament/en/displayFtu.html (pristupljeno 20.11.2014.)

Gulin, D. (2013) Pregled računovodstvene regulative i profesije u članicama EU, Računovodstvo i financije, 6/2013, Hrvatska zajednica računovodstvenih i financijskih delatnika, Zagreb.

IFRS for SMEs Basic for Conclusions, (2009) IASC Foundation Publications Department, London.

IFRS za SME, (2009) Međunarodni standard finansijskog izveštavanja za male i srednje entitete, Savez računovođa i revizora Srbije, Savez računovodja i revizora Republike Srpske i Institut sertifikovanih računovodja Crne Gore

Izveštaj o malim i srednjim preduzećima i preduzetništvu za 2012, (2013) Ministarstvo privrede, Ministarstvo regionalnog razvoja i lokalne samouprave i Nacionalna agencija za regionalni razvoj, Beograd

Krstić, J. (2002) Instrumenti finansijsko računovodstvenog izveštavanja, Ekonomski fakultet Niš

Krstić, J. and Đorđević, M. (2012) Interna kontrola i upravljanje rizikom preduzeća - od tradicionalnog do revidiranog COSO modela, Ekonomske teme, 50(2): 151-166.

Krstić, J. Jezdimirović, M. Đukić, T. (2013) Finansijsko računovodstvo, Ekonomski fakultet Niš.

Petković, S. and Berberović, Š. (2013) Ekonomika i upravljanje malim i srednjim preduzećima - principi i politike, Ekonomski fakultet Banja Luka.

Poljašević, J. (2011), Prihvatanje nove normativne osnove finansijskog izveštavanja za male i srednje entitete, 6. Kongres računovodja i revizora Crne Gore: Finansijsko izvještavanje u funkciji unapređenja poslovnog ambijenta u Crnoj Gori, Bečići, str. 301-313.

Radulović, M. (2006) Razvoj institucija i organizacija za podršku malim i srednjim preduzećima i preduzetništvu u Srbiji i uticaj inostranih iskustava (2001-2005), Republika Srbija, Republička agencija za razvoj malih i srednjih preduzeća i preduzetništva, Beograd.

Savet Evrope (2000) Evropska povelja o malim preduzećima, dostupno na http://www.vladars.net/sr-SP-Cyrl/Vlada/Ministarstva/mper/OM/upravorg/rstmt/ storg/Documents/Povelja\%20o\%20MSP.pdf (pristupljeno 25.11.2014.)

Stojanović, R. (2014) Razlike između Međunarodnog standarda finansijskog izveštavanja za male i srednje entitete i ,punih“ Međunarodnih standarda finansijskog izveštavanja, Računovodstvena praksa 20, str. 5-21.

Škarić Jovanović, K. (2011) Očekivanja i izazovi primene MSFI za mala i srednja preduzeća, 15. Kongres SRRRS: Refleksije medjunarodnih standarda finansijskog izvještavanja na računovodstvo, reviziju i poslovne finansije, Banja Vrućica, str. 13-38.

The IFRS for SMEs: Considering the alternatives, KPMG, January 2010.

Zakon o računovodstvu (2013), Službeni glasnik Republike Srbije, broj 62/2013. 


\section{NORMATIVNA OSNOVA FINANSIJSKOG IZVEŠTAVANJA MALIH I SREDNJIH ENTITETA U REPUBLICI SRBIJI}

Apstrakt: Mali i srednji entiteti predstavljaju posebnu grupu preduzeća u privredi jedne zemlje u smislu organizacije i ustrojstva finansijskog izveštavanja, prvenstveno za eksterne korisnike. Objavljivanjem Međunarodnog standarda finansijskog izveštavanja za male i srednje entitete priznato je da Međunarodni standardi finansijskog izveštavanja nisu usklađeni sa mogućnostima malih i srednjih entiteta, i da oni predstavljaju osnovu drugog nivoa finansijskog izveštavanja. Osnovni zadatak i cilj MSFI za MSE je pojednostavljivanje postojeće računovodstvene regulative za ovaj segment entiteta. U njemu su prepoznate specifične potrebe finansijskog izveštavanja malih i srednjih entiteta i specifični informacioni zahtevi ovog dela privrede. Jednostavnost primene kroz jednostavnije opcije vrednovanja i smanjena obelodanjivanja, smanjenje troškova pripreme izveštaja, kao i stalnost, predstavljaju neke od prednosti novog standarda.

Ključne reči: međunarodni standardi finansijskog izveštavanja, međunarodni standard finansijskog izveštavanja za male i srednje entitete, finansijski izveštaji, mali i srednji entiteti, Republika Srbija 